\title{
Technological challenges in oilseed crushing and refining ${ }^{\not / 3}$
}

\author{
Gabriel Krapf* \\ Received 31 January 2021 - Accepted 3 February 2021
}

World Health Day in April 2015 focused on food safety under the slogan "From farm to plate, make food safe" in order to draw global attention to the importance of food safety and its quality as a major challenge for the century.

For more than 150 years the world has been on an unwavering mission to sustainably nourish a global population. And now as the global population will grow from 7 billion today to more than 9 billion people by 2050 , the consumer values shift and climate change is real, the food processing and agriculture systems must evolve, being this is one of the biggest challenges for the oilseed processing industry: keep the food supply while diminishing wastes and contributing to the GHG reduction (Carre, 2021a).

Innovation in all its forms - technology, digitalization and applications - provides the means to address some of the challenges of the global food system: whether it's achieving zero hunger, delivering on consumer preferences, creating safer workplaces, offering transparency in our food system, replacing fossil compounds or improving farming technology.

Innovation is not a matter of a single company, universities or technological platforms. That is why the dossier included here shows different approaches for technologies improvements that would help the oilseeds processing sector to evolve.

Safety of edible oils but also edible proteins is a major challenge in the century and one that must be tackled for the protection of human health but also to assure the protein and fat autonomy of the territories and this has an important role in the trade and countries economy (Broudiscou et al., 2020). The challenge is how to get the oil fraction from the oilseeds but preserving the proteins quality in a more efficient way and eliminating the undesirable compounds with sustainable processing methods (Carre, 2021b).

An important challenge for the oil extraction process is the use (or not) of a solvent taking care of the economic, health and environmental issues. The well-known hexane extraction processing could be replaced by alternative and greener solvents or using specific surfactants, alternatives described in the articles includes in the "dossier" (Chaabani et al., 2019; Demarco and Gibon, 2020; Gharby et al., 2020; Gagnon et al., 2021).

\footnotetext{
it Contribution to the Topical Issue "Technological challenges in oilseed crushing and refining / Défis technologiques de la trituration et du raffinage des oléagineux".

*Correspondence: gmksolutions100@gmail.com
}

But the scientific approach of the behavior of the oilseeds in the expellers (Bogaert et al., 2020) and in general in the whole process of oilseeds processing is an important step forward to be able to understand and optimize the oilseeds processing, and then reducing the energy or solvent utilization keeping the proteins and oils quality intact.

The society is now looking much more on the naturality of the food and in this aspect the oils purification/refinery which allow to eliminate the undesirable compounds needs to find new ways to do it, by "inventing" the soft refinery either by enzymatic actions, bio sourced solvents or mechanical process (Bou Orm et al., 2020).

The challenges also imply the need to develop a system for the recovery of the co-products, effluent and waste from the agribusiness sector, by converting them into chemical molecules used to create new materials and products. (Laguna et al., 2020)

By creating a model in which the biodegradable organic carbon can be reused to produce materials is the challenge for our industry who then will be able to release on the market new chemical products derived from the recovery of products from the agricultural sectors for industrial and pharmaceutical applications, adding value to the oilseeds processing industry.

Finally, we should not forget the environment impact of the agriculture (like all industries) itself. Studies show that agriculture accounts for nearly $15 \%$ of global greenhouse gas emissions, while being at risk from rapid changes in climate. Agriculture can meet the rising demand for food, as farmers are resilient entrepreneurs who are increasingly doing more with less.

A partnership with farmers by investments in innovation and training will give farmers the tools they need to increase productivity and meet tomorrow's food demand: better technology, better seeds, more scale and mechanization without significantly expanding land use, and combining it with the technology innovation on the oilseed processing the challenge of tomorrow's food demand could be satisfy.

\section{References}

Bou Orm R, Citeau M, Comitis A, et al. 2020. Walnut oil deacidification by liquid-liquid extraction with ethanol in a single- and multistage crossflow process. OCL 27: 35.

Bogaert L, Mhemdi H, Vorobiev E. 2020. Residence time distribution and flow pattern modeling of oilseeds in a pilot screw press. $O C L$ 27: 65 . 
Broudiscou L-P, Laguna O, Lecomte J, Solé-Jamault V, Dauguet S. 2020. Methods assessment of self-tanning of rapeseed and sunflower meal fractions enriched in proteins and phenolic compounds using in vitro measurement of protein rumen degradability. OCL 27: 1.

Carre P. 2021a. Naturalness in the production of vegetable oils and proteins. OCL 28: 10.

Carre P. 2021b. Reinventing oilseed processing to extract oil while preserving the protein. $O C L$.

Chaabani E, Abert Vian M, Dakhlaoui S, Bourgou S, Chemat F, Ksouri R. 2019. Pistacia lentiscus L. edible oil: green extraction with bio-based solvents, metabolite profiling and in vitro antiinflammatory activity. $O C L$ 26: 25 .
Demarco A, Gibon V. 2020. Overview of the soybean process in the crushing industry. OCL 27: 60 .

Gagnon Y, Mhemdi H, Delbecq F, Van Hecke E. 2021. Extended surfactants and their tailored applications for vegetable oils extraction: An overview. OCL 28: 7.

Gharby S, Ravi HK, Guillaume D, Vian MA, Chemat F, Charrouf Z. 2020. 2-methyloxolane as alternative solvent for lipid extraction and its effect on the cactus (Opuntia ficus-indica L.) seed oil fractions. $O C L$ 27: 27.

Laguna O, Guyot S, Yu X, et al. 2020. The PHENOLEO project or how to separate and add-value to phenolic compounds present in rapeseed and sunflower meals. OCL 27: 61 .

Cite this article as: Krapf G. 2021. Technological challenges in oilseed crushing and refining. OCL 28: 18. 